\title{
The Margo (mar) Seedcoat Color Gene Is a Synonym for the Joker $(j)$ Locus in Common Bean
}

\author{
Mark J. Bassett ${ }^{1}$ \\ Horticultural Sciences Department, Institute of Food and Agricultural Sciences, University of Florida, \\ Gainesville, FL 32611
}

Additional index words. Phaseolus vulgaris, inheritance, allelism tests, genetic linkage

\begin{abstract}
The inheritance of hilum ring color in common bean (Phaseolus vulgaris L.) was investigated using various genetic tester stocks developed by backcrossing recessive alleles into a recurrent parent stock 5-593 with seedcoat genotype $P[C r] D J G B V R k$, viz., mar $\mathrm{BC}_{2}$ 5-593, mar $\mathrm{BC}_{3}$ 5-593, mar $v \mathrm{BC}_{2} 5-593$, mar $d \mathrm{BC}_{2}$ 5-593, and mar $d_{\mathrm{BC}_{3}}$ 5-593. The current hypothesis is that the margo character is controlled by mar and hilum ring color is controlled by $d$ but expresses only with $m a r$. The $V$ locus controls flower and seedcoat color. The allelism test crosses 'Citroen' $(P C d j g b$ lae $) \times$ mar $\mathrm{BC}_{3}$ 5-593 and 'Citroen' $\mathrm{x}$ mar $d \mathrm{BC}_{3}$ 5-593 demonstrated that $m a r$ is allelic with $j$ and that the putative $d$ in $m a r d$ BC 5 -

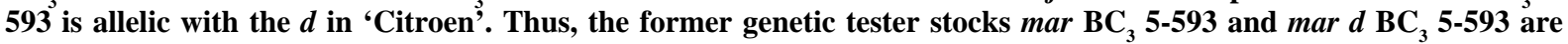
reclassified as $j \mathrm{BC}_{3} 5-593$ and $d j \mathrm{BC}_{3} 5-593$, respectively, because $m a r$ is a synonym for $j$. Similarly, the former genetic tester stock mar $v \mathrm{BC}_{2}$ 5-593 is reclassified as $j v \mathrm{BC}_{2}$ 5-593. The interaction of $j$ with $d$ expresses as loss of color in the hilum ring. The development of the white-seeded genetic tester stock $P c^{\mathrm{u}} d j \mathrm{BC}_{3}$ 5-593 was described in detail, where the allrecessive tester 'Prakken 75' was used as the source of the recessive alleles. The previously reported work showing that the partly colored seedcoat gene $t$ interacts with mar to control seedcoat pattern is now interpreted to mean that the joker $(J)$ locus interacts with $t$ to produce partly colored seedcoat patterns. The genetic loci $D$ and $V$ were found to segregate independently. The common gene for dull seedcoats (asper, asp) is discussed and contrasted with $j$.
\end{abstract}

Prakken (1970) wrote a comprehensive, critical review of all previous work on the genetics of seedcoat colors of common bean (Phaseolus vulgaris), except for the red colors. There was a dispute between Prakken (1970) and Lamprecht (1951) concerning the genetic control of the color of the hilum ring that continued over the career of Lamprecht (1932-64). The hypothesis of Prakken (1970) was that hilum ring color (vs. white) was produced by the action of either of two color genes ( $D$ or $J$ ), whereas the hypothesis of Lamprecht (1951) was that hilum ring color could be conferred by each of the color genes J, Ins, Can, $G$, and $B$. The hypothesis of Prakken (1970) was retested in the work reported below.

Lamprecht (1933) reported a seedcoat pattern character, margo, that is controlled by a single recessive gene ( $\mathrm{mar}$ ) that is expressed only in the genotype $P$ cjg $B$ v mar in progeny derived from selfing the genotype $P P C c J j$ gg Bb vv Marmar. The margo seedcoat pattern gives the genetically expected seedcoat color in a broad swath about the hilum but produces a paler color in the remainder of the seedcoat. Lamprecht (1951) also attributed expression of the margo character to mar in the genotype $P c j G b v$ mar. Quoting from an English translation of Lamprecht's (1951) paper, "The effect of the recessive gene mar can thus be defined as follows: at the location of the band [a broad swath of darker color about the hilum], mar causes local transformation of the gene $j$ into $J$, or: the effect of mar together with $j$ at the location of the band determines the presence of the testa color otherwise determined by $J$ together with the remaining genotypical constitution." It is my hypothesis that no gene mar, independent of $J$, exists. The banding patterns attributed to $j$ mar are really just expressions of $j$, which Lamprecht $(1933,1951)$ particularly noticed in certain genetic backgrounds. The primary effect of the joker gene ( $j$ ), as noted by Prakken (1970, 1972), is to produce a unique color difference in nearly every

Received for publication 4 Mar. 1996. Accepted for publication 26 July 1996. Florida Agricultural Experiment Station journal series R-04749. I thank Hallie Smith (formerly with the Graphics Dept., Office of Instructional Resources, Univ. of Florida, for drawing the illustrations. The cost of publishing this paper was defrayed in part by the payment of page charges. Under postal regulations, this paper therefore must be hereby marked advertisement solely to indicate this fact. ${ }^{1}$ Professor. genetic background into which it is substituted for $J$. The color is always paler than its $J$ counterpart. The secondary effect of $j$ is to produce a mat or dull seedcoat that is much less subject to afterdarkening than with $J$. A tertiary effect of $j$ (once the synonymous character of mar and $j$ is established below) is to strongly reduce color in the corona zone with $v$, more moderately (and variably) reduce corona color with $V$, and reduce corona color least (and most variably) with $v^{\text {lae }}$ (Bassett, 1994a).

In 1989, I began a study of Herbert Lamprecht's seed collection of common beans, which is now available under the USDA plant introduction (PI) accession numbers 527711 through 527878 and is maintained at Pullman, Wash. Although only PI 527742 is listed as carrying mar in the genetic notes, I was able to demonstrate that PI lines 527753 and 527806 also carry mar (Bassett, 1994a). This paper reports the results of allelism tests and other test crosses between

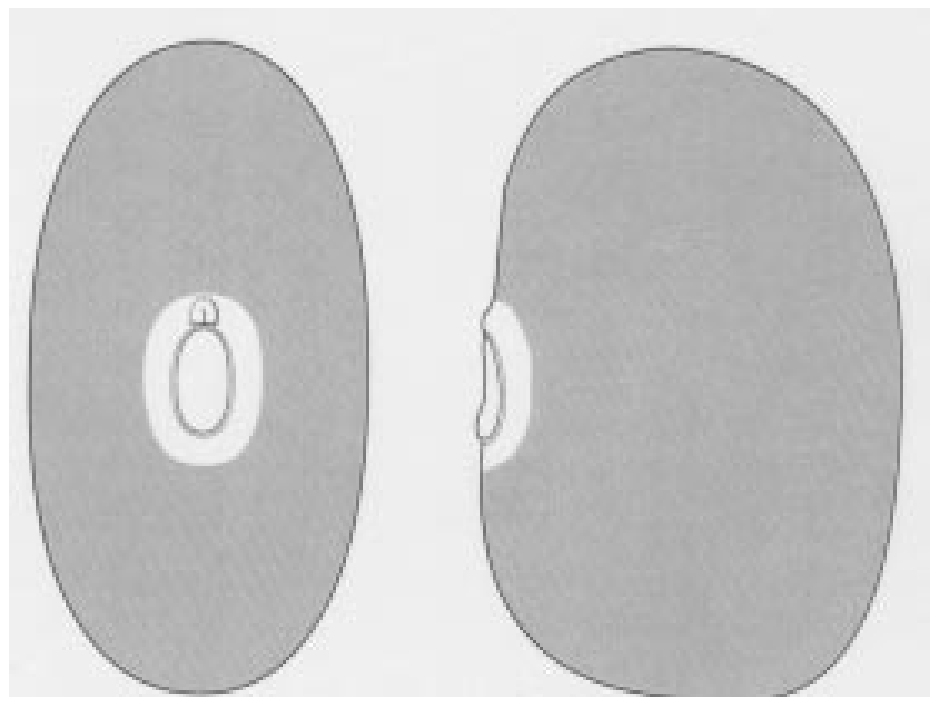

Fig. 1. Seeds with the colorless (white) hilum ring and corona zone produced by $d$ $j \mathrm{BC}_{3} 5-593$. The gray remainder of the seedcoat signifies the mat dark purple seedocat color (vs. the shiny black of 5-593). No contrast between the typically darker colored margo region and the remainder is illustrated here. 
Table 1. Segregation for color of hilum ring and flower in the $\mathrm{F}_{2}$ of the cross $d j \mathrm{BC}_{2} 5-593 \times j v \mathrm{BC}_{2} 5-593$.

\begin{tabular}{|c|c|c|c|c|c|}
\hline \multicolumn{2}{|c|}{ Black hilum ring } & \multicolumn{2}{|c|}{ White hilum ring } & \multirow[b]{3}{*}{$\chi^{2}$} & \multirow[b]{4}{*}{$P$} \\
\hline Purple & White & Purple & $\overline{\text { White }}$ & & \\
\hline flowers & flowers & flowers & flowers & & \\
\hline$D /-V /-$ & $D /-v / v$ & $d / d V /-$ & $d / d v / v$ & $9: 3: 3: 1^{z}$ & \\
\hline$\overline{600}$ & 182 & 190 & 69 & 1.623 & 0.65 \\
\hline
\end{tabular}

stocks carrying mar and various genetically defined tester stocks, with special emphasis on testing for the allelism of $m a r$ and $j$.

\section{Materials and Methods}

In 1985 I initiated a program to develop genetic stocks with selected marker genes of common bean in a common genetic background by backcrossing to a recurrent parent. The recurrent parent was a Florida dry bean breeding line, 5-593, which has the black seedcoat genotype $P[C r] D J G B V R k$ (Bassett, 1994b; Prakken, 1970). Recessive genes for seedcoat color have received special attention in the program, and the donor genes are usually taken to $\mathrm{BC}_{3}$ into the recurrent parent background. The backcross method used to develop all the genetic tester stocks was described in detail elsewhere (Bassett, 1994c).

The genetic tester stocks mar $\mathrm{BC}_{2}$ 5-593 and mar $\mathrm{BC}_{3}$ 5-593 were developed from PI 527753. The phenotype of the mar $\mathrm{BC}_{3} 5$ 593 tester stock was illustrated (using materials derived from PI 527753 and 527806) with color photographs elsewhere (see Fig. 1, rows 1 and 2, columns 2-5, in Bassett, 1994a). The three principal effects of mar are loss of seedcoat shininess, production of a paler (more immature) seedcoat color except in the margo zone, and strong loss of color (often nearly white) in the corona zone (Bassett, 1994a). The genetic tester stock mar $v \mathrm{BC}_{2} 5-593$ was created synthetically from the cross $\operatorname{mar} \mathrm{BC}_{2} 5-593 \times v \mathrm{BC}_{2} 5-593$ (data not shown). The source of the $v$ allele in the genetic tester stock $v \mathrm{BC}_{2} 5-593$ was Lamprecht line M0056 (now PI 527830).

PI 527806 had white flowers and bluish violet seedcoats with a colorless hilum ring and nearly white corona. PI 527806 not only has mar phenotype but also has colorless hilum ring (Bassett, 1994a), which is attributed to the action of the hilum ring factor $d$ of Prakken (1970). The genetic tester stocks mar $d \mathrm{BC}_{2} 5-593$ and mar $d \mathrm{BC}_{3}$ 5-593 were developed from PI 527806, and the hypothetical presence of $d$ will be tested below. The genotype mar $d$ produces a white hilum ring and corona in addition to the usual effects of mar (Fig. 1).

In 1975, M.H. Dickson, formerly with the Dept. of Horticultural Sciences, Cornell Univ., Geneva, N.Y., sent me a seed stock that he had received from R. Prakken, Wageningen, the Netherlands. The stock was described as an all-recessive tester, designated here as 'Prakken 75', and presumed to have the genotype $P c d j g b v^{\text {lae }}$ or $P c d j G b v^{\text {lae }}$, having pink flowers (due to $v^{\text {lae }}$ ) and pure white seedcoats (due to $c d j$ ). Prakken (1940) developed such white seeded stocks from the cross 'Citroen' race $\left(P C d j G b v^{\text {lae }}\right) \times$ Hilumring type ( $P$ c D j $\left.g b v^{\text {lae }}\right)$.

In 1994 I obtained seed of 'Citroen' from H. Dijkstra, Collection Manager, Centre for Genetic Resources, Wageningen. Prakken (1940) made a detailed study of $F_{2}$ progeny from the cross 'Wagenaar' $x$ 'Citroen', followed by very extensive $F_{3}$ progeny tests. Prakken (1972) also made a detailed analysis of a set of diallel crosses among 'Citroen', 'Kievit', 'Wagenaar', and 'Hinrich's R.' Based on those studies, Prakken (1972) concluded that the seedcoat genotype of his selection of 'Citroen' is $P T C d j G b v^{\text {lae }} R k$.

Allelism and linkage tests. In Winter 1995 'Citroen’ was crossed to $\operatorname{mar} \mathrm{BC}_{3}$ 5-593 and mar $d \mathrm{BC}_{3}$ 5-593. The $\mathrm{F}_{1}$ progenies were planted in the field in Spring 1995, and data were taken on the color of flowers and seeds.

In Winter 1994, 'Prakken 75' was crossed to $\operatorname{mar} d \mathrm{BC}_{2}$ 5-593. The $\mathrm{F}_{1}$ progeny were planted in the field in Spring 1994, and data were taken on the color of flowers and seeds.

In Winter 1993 the cross $\operatorname{mar} d \mathrm{BC}_{2} 5-593 \times \operatorname{mar} v \mathrm{BC}_{2} 5-593$ was made and the $\mathrm{F}_{2}$ progeny were planted in the field in Spring 1994. Data were taken on the color of flowers and seedcoats.

Crosses with 'Prakken 75' and derivatives. In 1987, the cross 'Prakken 75 ' $\times$ 5-593 was made and the $\mathrm{F}_{2}$ was grown in the field in Spring 1988. Seeds were fully harvested from more than $300 \mathrm{~F}_{2}$ plants and a seed sample from each plant was put in a separate transparent ziplock plastic bag $(7.6 \times 12.7 \mathrm{~cm})$ to facilitate classification into seedcoat color classes. Selections were made in $\mathrm{F}_{2}$ and $\mathrm{F}_{3}$ for plants with pure white seedcoat and bishops-violet (purple) flowers (due to $V / V$, Bassett et al., 1990), which was presumed to have the seedcoat genotype $P c d j$ and designated $\mathrm{F}_{3} P c d j$. The backcross $\mathrm{F}_{3} P c d j \times 5-593$ was made and the $\mathrm{BC}_{1}-\mathrm{F}_{2}$ was grown in the field in Spring 1989. A selection was again made for a plant with pure white seedcoat and for purple flowers $(V / V)$, which was designated $P c d j \mathrm{BC}_{1}$ 5-593. The second backcross to 5-593 was made in 1989 and the $\mathrm{BC}_{2}-\mathrm{F}_{2}$ was planted in the field in Spring 1990. Data were taken on flower and seedcoat color in $F_{1}$ and $F_{2}$ progeny. At this point in the development, the $c$ allele was recognized to be the $c^{\mathrm{u}}$ allele for unchangeable cartridge buff seedcoats (Prakken, 1970). The third backcross, $P c^{\mathrm{u}} d j \mathrm{BC}_{2} 5-593$ $x$ 5-593, was made in 1992 and the $\mathrm{BC}_{3}-\mathrm{F}_{2}$ was grown in the field in Spring 1993. Data were taken on flower and seedcoat color, and a detailed classification was achieved.

Table 2. Segregation for seedcoat colors in the $\mathrm{F}_{2}$ from the cross $P c d j \mathrm{BC}_{1} 5-593 \times 5-593$, where all $\mathrm{BC}_{2}-\mathrm{F}_{2}$ plants had purple flowers $(V / V)$.

\begin{tabular}{lcccc}
\hline \hline \multicolumn{3}{c}{ Seedcoat colors/genotypes } & & \\
Black & & & & \\
and purple & Cartridge & & \\
$C J$ & buff & Pure & $\chi^{2}$ & $P$ \\
$C j$ & $c^{\mathrm{u} J}$ & white & $48: 15: 1$ & 0.48 \\
$d j$ & $c^{\mathrm{u}} j$ & $c^{\mathrm{u}} d j$ & 1.481 & \\
\hline 155 & 58 & 4 & & \\
\hline
\end{tabular}


Table 3. Segregation for seedcoat colors in the $\mathrm{BC}_{3}-\mathrm{F}_{2}$ from the cross $P c^{\mathrm{u}} d j \mathrm{BC}_{2} 5-593 \times 5-593$.

\begin{tabular}{|c|c|c|c|c|c|c|c|}
\hline \multicolumn{6}{|c|}{ Seedcoat colors/genotypes } & \multirow[b]{4}{*}{$\chi^{2}$} & \multirow[b]{5}{*}{$P$} \\
\hline & Cartridge & & Pale & Margo & & & \\
\hline Black & buff & & cartridge & without & Pure & & \\
\hline$C J$ & $c^{\mathrm{u}} J$ & Margo & buff $^{z}$ & hilum ring ${ }^{y}$ & white $^{\mathrm{x}}$ & & \\
\hline$C d J$ & $c^{\mathrm{u}} d J$ & $C D j$ & $c^{\mathrm{u}} D j$ & $C d j$ & $c^{\mathrm{u}} d j$ & $36: 12: 9: 3: 3: 1$ & \\
\hline$\overline{276}$ & 80 & 66 & 19 & 16 & 7 & 3.310 & 0.65 \\
\hline
\end{tabular}

${ }^{\mathrm{z}}$ Has black hilum ring.

${ }^{y}$ Hilum ring is pure white, i.e., the black hilum ring is absent.

${ }^{x}$ Has no hilum ring. For the data 457 colored seedcoat to 7 white seedcoat the $\chi^{2}(63: 1)=0.009, P=0.93$.

\section{Results and Discussion}

Allelism and linkage tests. The $\mathrm{F}_{1}$ plants from the cross 'Citroen' $\mathrm{x}$ mar $\mathrm{BC}_{3} 5-593$ had cobalt-violet flowers due to $V / v^{\text {lae }}$ (Bassett et al., 1990) and nonshiny (dull, mat) seeds with dark purple color (including the hilulm ring) and nearly white corona zones (data not shown). The observed seedcoat color was an allelic response, indicating that 'Citroen' must carry mar. All other recessive alleles for seedcoat color in 'Citroen' were masked in the $\mathrm{F}_{1}$ plants by the dominant alleles in the $\operatorname{mar} \mathrm{BC}_{3} 5-593$ tester. There is no doubt that Prakken $(1940,1970)$ had identified all the recessive alleles for seedcoat color carried by 'Citroen', viz., $d, j, b, v^{\text {lae }}$ with no mention of mar. Therefore, mar must be a synonym for one of those genes. The synonym cannot be $v^{\text {lae }}$ because it produces mineral brown seedcoats not in evidence in the tester. It cannot be $d$ because $j$ and $d$ must be recessive for $d$ to express (Prakken, 1940), and the mar $\mathrm{BC}_{3}$ 5-593 tester carries only one recessive substitution for seedcoat color. It cannot be $b$ because $b$ does not produce a nonshiny seedcoat nor the loss of color in the corona zone. By elimination, the synonym must be $j$. This conclusion is corroborated by the fact that $j$ is well known for the loss of seedcoat luster (nonshininess) (Prakken, 1940, 1970). Thus, the mar BC $35-593$ tester must really be a $j \mathrm{BC}_{3} 5-593$ tester. Also, the allelic response confirms the hypothesis that the $j$ allele expresses the margo color pattern, which gives the mature seed color in the margo zone and slightly immature color on the remainder of the seedcoat (Bassett, 1994a),

The fact that mar is a synonym for $j$ requires a revision of the interpretation of previously published work on the interaction of the gene for partly colored seedcoats $(t)$ with the margo gene ( $m a r)$ (Bassett, 1994a). The joker $(J)$ locus must now be added to the list of genes that control pattern expression with $t$ (Bassett, 1994a, 1995a).

The $\mathrm{F}_{1}$ plants from the cross 'Citroen' $\mathrm{x}$ mar $d \mathrm{BC}_{3}$ 5-593 tester had cobalt-violet flowers due to $V / v^{\text {lae }}$ (Bassett et al., 1990) and nonshiny dark purple seedcoats with white hilum ring and white corona zone (data not shown). The observed data are a result of allelism between 'Citroen' and both recessive genes carried by mar $d \mathrm{BC}_{3}$ 5-593. The mar gene must correspond to the $j$ of 'Citroen' as with the allelism test with $\operatorname{mar} \mathrm{BC}_{3}$ 5-593, and the hypothetical $d$ in $\operatorname{mar} d \mathrm{BC}_{3} 5-593$ must be allelic with the wellestablished hilum ring factor $d$ in 'Citroen' (Prakken, 1940, 1970). Thus, the $\operatorname{mar} d \mathrm{BC}_{3} 5-593$ tester is reinterpreted to be a $d j \mathrm{BC}_{3} 5$ 593 tester.

The results of the allelism tests with 'Citroen' have decisive implications for the dispute between Prakken (1970) and Lamprecht (1951) over the genetic control of color in the hilum ring. The genetic tester stocks mar $\mathrm{BC}_{3}$ 5-593 and $\operatorname{mar} d \mathrm{BC}_{3}$ 5-593 carry $B$ $V$ (M.J. Bassett, unpublished data). Thus, the $\mathrm{F}_{1}$ progenies of both allelism test crosses carry $B / b V / v^{\text {lae }}$, but the test cross with mar $d$ $\mathrm{BC}_{3}$ 5-593 does not express hilum ring color in $\mathrm{F}_{1}$ because that tester also carries $d / d j / j$. Those results lead to a rejection of the hypothesis of Lamprecht (1951) and strongly support the hypothesis of Prakken (1970).

Based on the above results, the cross $\operatorname{mar} d \mathrm{BC}_{2} 5-593 \times$ mar $v$ $\mathrm{BC}_{2}$ 5-593 described above should now be designated as $d j \mathrm{BC}_{2} 5-$ $593 \times j v \mathrm{BC}_{2} 5-593$. In the $\mathrm{F}_{2}$ progeny, the color of flowers and hilum rings segregated independently, i.e., the genetic loci $D$ (controlling hilum ring color) and $V$ (controlling flower color) are independent loci (Table 1). Those results do not agree with previously published findings of Lamprecht (1961), in which the linkage between $D$ and Cor (dark corona) is 31 centimorgans (Bassett, 1991). Recently it was discovered that the dark corona character is controlled by the ${ }^{\text {lae }}$ allele (Bassett, 1995b); hence, the linkage of Lamprecht (1961) between $D$ and Cor becomes linkage between $D$ and $V$ because $C o r$ is a synonym for $v^{\text {lae }}$. The earlier work (Lamprecht, 1961) appears to be in error because the scale of the present experiment was adequate to have detected the expected linkage if it existed (Table 1).

In his summary treatises on seedcoat color, Prakken (1970, 19972) made no mention of the margo (mar) gene of Lamprecht (1933). I speculate that Prakken regarded mar as a synonym for $j$, recognizing that the margo patterning was simply a typical $j$ effect that is more prominent (produces higher contrast between the margo zone and the remainder) in some genetic backgrounds than others. In my observations over many years, the margo patterning effect of $j$ is highly variable and is accentuated by stressful growing conditions. For example, it is more prominent with field than greenhouse culture. Another interesting variation that I have observed with $j$ is the occurrence of color expression as fine stippling on the seedcoat, viz., dark purple dots on a paler grayish purple background (M.J. Bassett, unpublished data).

There is another gene (besides $j$ ) that produces dull seedcoat appearance that is widely distributed in dry bean germplasm, viz., the asper (asp) gene of Lamprecht (1940). I have observed that the loss of seedcoat shininess produced by $a s p$ is greater and more stable than that of $j$. Also, asp has no effect on seedcoat color, whereas $j$ always produces a paler seedcoat color than with $J$ in any genetic background that is not already white with $J$ (Prakken, 1970, 1972). In fact, the $j$ effect on seedcoat color (hue) is its most prominent effect (Bassett, 1994a). The asp locus is nonallelic with $j$ (M.J. Bassett, unpublished data).

The $j$ allele produces a highly variable loss of color in the corona region with $V$ and a more predictable (less variable from seed to seed) loss with $v$ (Bassett, 1994a). The $j$ allele also produces some loss of the dark corona color expressed with $v^{\text {lae }}$, but that loss rarely approaches a colorless state (M.J. Bassett, unpublished data). Prakken (1972) probably failed to detect the linkage (or pleiotropy) between $v^{\text {lae }}$ and darkly pigmented corona for the following reasons. Prakken's (1972) only parent that carried $j$ ('Citroen') was crossed only with parents that carried $v^{\text {lae }}$, e.g., 'Wagenaar', 'Citroen', 'Kievit', and 'Hinrich's R'. Similarly, his only parent that carried $v$ ('White $\mathrm{J}$ ') was crossed only with parents that carried 
J, e.g., 'Wagenaar', 'Yellowbrown J', 'White J', and 'Soldaat K' . If he had crossed 'Citroen' $x$ 'White J', he would probably have made the linkage discovery of Bassett (1995b).

Crosses with 'Prakken 75' and derivatives. The $\mathrm{F}_{2}$ progeny from the cross 'Prakken 75 ' $\times$ 5-593 could not be classified for seedcoat color. The transparent plastic bags, each with a seed sample from a different $\mathrm{F}_{2}$ plant, were laid out on a large, wellilluminated, light colored table in a continuous array of colors from white to black, but it was not possible to clearly establish the phenotypic class boundaries for most classes (data not shown). One color blended into the next. This difficulty came as a surprise because previous authors (reviewed by Prakken, 1970) were able to make unambiguous classifications of segregating progenies into the phenotypic classes expected from the above cross. Nevertheless, it was possible to select for plants with pure white seedcoats and purple flowers (putative genotype $P c d j$ ) and use these in backcrosses to 5-593 (see Methods and Materials).

The second backcross to 5-593, viz., $P$ c dj $\mathrm{BC}_{1}$ 5-593 x 5-593, produced $F_{1}$ plants with purple flowers and shiny pure black seeds. The $\mathrm{F}_{2}$ was classified into three phenotypic classes, for which a full genotypic interpretation was possible (Table 2). The data fit a three-gene hypothesis that specifies the interaction of the recessive alleles $c^{\mathrm{u}}, d$, and $j$, which produces a pure white seedcoat. The new genetic interpretation replaces the generic $c$ allele action and specifies the unchangeable cartridge buff allele $\left(c^{\mathrm{u}}\right)$ at $C$. Although the material was classified in 1990, the complete genetic interpretation of the classes was not possible until 1993.

During 1991 and 1992, I made an extensive survey of the materials in the Lamprecht seed collection and I became well acquainted with the effects of the recessive margo gene (now $j$ ) in the presence of $V$. Thus, when a third backcross of the putative $P$ $c d j \mathrm{BC}_{2}$ 5-593 to 5-593 was made, it was possible to analyze fully all the phenotypic classes for the first time in the $\mathrm{BC}_{3}-\mathrm{F}_{2}$ progeny (Table 3). The six seedcoat classes were as follows. The shiny pure black seeds were due to $C J$, where the allelic constitution at $D$ has no expression. The cartridge buff class seeds were due to $c^{\mathrm{u}} J$, where the allelic constitution at $D$ has no expression. The margo class seedcoats were due to $C D j$, where the hilum ring was black, the corona was nearly white, the margo region was nearly black, and the remainder was dark purple to gray brown (margo effects were highly variable). The pale cartridge buff class seeds were due to $c^{\mathrm{u}} D j$, where the brown hilum ring is the only strongly colored feature of the seedcoat (same as the hilum ring type of Prakken, 1940). The margo with colorless hilum ring class was due to $C d$ $j$, where the hilum ring is pure white, the corona in nearly white, and the remainder is typical for margo with $V$ (see $C D j$ above). Finally, the pure white seeds were due to $c^{\mathrm{u}} d j$, the triple recessive class. The seven segregants for pure white seeds among 464 total progeny gave a very good fit to the expected 63:1 ratio, and the six class genetic model gave a good fit to the expected $36: 12: 9: 3: 3: 1$ ratio of phenotypic classes of seedcoat color and pattern (Table 3 ).

\section{Literature Cited}

Bassett, M.J. 1991. A revised linkage map of common bean. HortScience 26:834-836.

Bassett, M.J. 1994a. The margo (mar) seedcoat character and the $t$ mar interaction in common bean. J. Hered. 85:404-407.

Bassett, M.J. 1994b. The genotype for seedcoat color of breeding line 5593. Annu. Rpt. Bean Improv. Coop. 37:244-245.

Bassett, M.J. 1994c. The griseoalbus (gray-white) seedcoat color is controlled by an allele $\left(p^{\text {gri }}\right)$ at the $P$ locus in common bean. HortScience 29:1178-1179.

Bassett, M.J. 1995a. Translation (German to English) of the 1940 papers by Lamprecht and Schreiber on partly colored seeds and a critical review. Annu. Rpt. Bean Improv. Coop. 38:11-12.

Bassett, M.J. 1995b. The dark corona character in seedcoats of common bean cosegregates with the pink flower allele $v^{\text {lae }}$. J. Amer. Soc. Hort. Sci. 120:520-522.

Bassett, M.J., L.B. Xue, and C. Hannah. 1990. Flower colors in common bean produced by interactions of the $S a l$ and $V$ loci and a gametophyte factor $G a$ linked to Sal. J. Amer. Soc. Hort. Sci. 115:1029-1033.

Lamprecht, H. 1933. Zur Genetik von Phaseolus vulgaris. VI. Vierter Beitrag zur Vererbung der Testafarbe. Hereditas 17:249-316.

Lamprecht, H. 1940. Zur Genetik von Phaseolus vulgaris. XVII-XVIII. Zwei neue Gene für Abzeichen auf der Testa, Punc und Mip, sowie über die Wirkung von $V$ und Inh. Hereditas 26:292-304.

Lamprecht, H. 1951. Die Vererbung der Testfarbe bei Phaseolus vulgaris L. Agr. Hort. Genet. 9:18-83.

Lamprecht, H. 1961. Weitere Koppelungsstudien an Phaseolus vulgaris mit einer Übersicht über die Koppelungsgruppen. Agr. Hort. Genet. 19:319-332.

Mather, K. 1957. The measurement of linkage in heredity. Wiley, London. Prakken, R. 1940. Inheritance of colours in Phaseolus vulgaris L. I. Genetica 22:331-408.

Prakken, R. 1970. Inheritance of colour in Phaseolus vulgaris L. II. Critical review. Meded. Landbouwhogeschool Wageningen 70-23:138.

Prakken, R. 1972. Inheritance of colours in Phaseolus vulgaris L. III. On genes for red seedcoat colour and a general synthesis. Meded. Landbouwhogeschool Wageningen 72-29:1-82. 